Case Report

\title{
Physical Illness and Emotional Expression in Late Life
}

\author{
Elizabeth Midlarsky*
}

Teachers College, Columbia University, New York, NY, United States; E-Mail: erm142@gmail.com

* Correspondence: Elizabeth Midlarsky; E-Mail: erm142@gmail.com

Academic Editor: Ray Marks

Special Issue: Depression and Aging: Role of Social Support

\section{OBM Geriatrics}

2019, volume 3, issue 4

doi:10.21926/obm.geriatr.1904088
Received: August 18, 2019

Accepted: November 19, 2019

Published: November 25, 2019

\begin{abstract}
Louise H., Ph.D was referred to me by her long-term primary care physician (PCP) who was certain that his patient was seriously depressed and in need of medication and possibly psychotherapy. My own assessment, in consultation with a neurologist, was that Louise's problems with coping were primarily neurological, and that her issues were due to serious (and in one case embarrassing) symptoms. Her neurological problems (mild Parkinsonism and PseudoBulbar Affect, or PBA) are currently being addressed by the neurologist, and psychotherapy is being employed to enhance her coping with these symptoms, and to enhance her well-being.
\end{abstract}

\section{Keywords}

Physical illness; emotional expression; late life; depression

\section{Introduction}

Louise $\mathrm{H}$ was referred to me by her primary care physician (PCP). He described her as a longterm patient of his who appeared to be depressed and in need of psychotherapy. In his opinion,

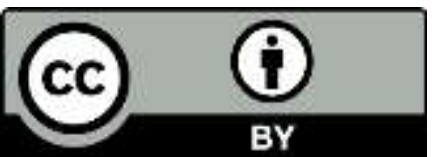

(C) 2019 by the author. This is an open access article distributed under the conditions of the Creative Commons by Attribution License, which permits unrestricted use, distribution, and reproduction in any medium or format, provided the original work is correctly cited. 
she was the kind of person who would be a good candidate for psychotherapy.

Louise was described as an exceptionally cultured and well-adjusted Scandinavian-origin woman who was, in his opinion, depressed because of the "devasting" changes in her due to aging. He sadly, and quite emotionally described her as someone who, as recently as two years previously, was a very tall (5'11 1/2"), athletic-appearing woman whose slender figure, sandycolored hair, and bright blue eyes combined to create a strikingly attractive picture. In addition to an attractive physical appearance, was described as having had excellent personal qualities, including extreme competence, refinement and warmth. This "favorite patient" had generally been a physically healthy person, whose problems at menopause several years previously were readily managed by a well-tolerated regime of hormone therapy. She came in regularly for scheduled physical examinations, and presented no unfounded somatic complaints. When ill, she offered a clear and parsimonious description of her symptoms, and faithfully complied with any prescribed treatment. The current depressive symptomatology was, in the words of her (depressed-sounding) physician, part of the "disease of her aging"--which was resulting in such noticeable physical changes as apparent height loss (possibly because of her posture, at least in part), and a certain amount of difficulty walking. While she had previously seemed "young for her age," now, he believed, she seemed "old for her age"--a "depressing change," he thought.

When 67-year-old Louise $\mathrm{H}$. came, quite promptly, for her initial session, my receptionist overlooked her at first. She appeared to be much older than we were told--at least in her middle seventies. Closer observation indicated that much of the impression of "old age" came from her gait. While she had reportedly, until very recently, been active and excelled at several sports including swimming, tennis and running, and had been described as having had an "athletic stride," there were hints of what has been described as the "Parkinsonian gait" or "marche"--a walk with relatively short steps, in which the person appears to shuffle, leaning forward, with no swinging of the arms. In addition from time to time, there was also the slightest hint of a tremor in her hand.

Indeed, there was an almost unmistakable suggestion, from her physical appearance, of a neurological problem.

Now depressive symptomatology is a common mental health problem among older adults, and particularly among older women [1-4]. While an estimated $14.7 \%$ of adults 65 years of age and older are depressed, the largest single group, 6.5\%, are suffering from dysphoric disorders secondary to health problems [1], so that it may be necessary to investigate such problems prior to making a formal diagnosis and treatment plan. Furthermore, depressive symptoms (but not depressive disease, such as major depression) are related to three major neurological disorders: stroke, dementia, and idiographic Parkinson's disease [5]. While there is no clear evidence of the direction of causation, and reciprocal causation is probable in many cases, approximately $20 \%$ of people with Parkinson's disease start experiencing depressive symptoms prior to the determination of the disease [6].

My concern about the possibility of a neurological problem after seeing her, prompted me to speak to Louise $\mathrm{H}$. about the possibility that her unhappy mood and other symptoms--the difficulty walking, engaging in sports, and frequent bouts of uncontrollable crying--might be due, at least in part, to neurological problems. Although her primary care physician had recently told her that she appeared to be depressed, she did not feel depressed. Her own primary reaction to her crying outbursts was embarrassment at the public displays along with puzzlement, as the outbursts were 
not reflections of her feelings. With her permission, I telephoned her primary care physician in her presence, voiced my concern, and asked that he consider a neurological consultation. I also told that if, at some point, she wanted a referral to a mental health professional I would be happy to give her suggestions about how to proceed.

A little over a month after the session, I learned that the neurologist had found that Louise was suffering from mild Parkinson's disease, which was in a very early stage. She was given two medications (Sinemet and Eldepryl) which, it was hoped, would provide symptom relief and also slow down the course of the disease. In addition, he planned to obtain a thorough picture of any possible brain injury, as part of an assessment of PBA-Pseudo Bulbar Affect. Louise was indeed diagnosed as having PBA, a disease that is not curable, but is manageable through mood stabilizers [7]. PBA is evidenced by a vastly exaggerated and uncontrollable outburst of laughing or crying. The crying or laughing which is either totally unwarranted or highly exaggerated is upsetting to the patient. Louise was given a tricyclic antidepressant, which reduced the strength and frequency of the outbursts. Louise and her husband were planning to leave for an extended trip to Florida where they own a home, and the plan was to have the effects of the treatment monitored by a physician there.

During the latter part of November, Louise telephoned. She said that she and her husband had spent several months in Florida, returning to New Jersey in October. For some reason, although her Parkinsonian symptoms were apparently under control, she was again feeling quite unhappy, and wanted to speak to a mental health professional about her feelings. Her physician again recommended psychotherapy; at this second referral, she decided to call me. She said that after speaking with me several months earlier, she had decided that if she did choose psychotherapy, she preferred to work with me.

\section{Personal Data and Appearance}

Louise $\mathrm{H}$ is at present a 67-year-old married woman, who describes her long-term marriage as stable, and for the most part as happy. She and her husband have one adult son. They own a fivebedroom house in New Jersey, a two-bedroom apartment in Florida, and a seven-year-old car. While they live alone, they described a house which over the years was filled with music and books, and friends and family whom they entertained and who frequently stayed with them, "filling the space." This has happened far less since she started becoming ill, and retired.

No history of psychiatric hospitalizations or psychotropic medications was reported. Her only experience with psychological intervention was a brief (three-month) series of counseling sessions, initiated at her request 35 years ago (at age 32). She felt she needed counseling when she had trouble coping following a long and difficult pregnancy, after which she gave birth to her one son, a "blue baby"--resulting from Erythroblastosis Fatalis (due to previously undiagnosed Rh incompatibility between mother and son). Exhausted and depleted, seeing her son's apparent frailty, and learning that she would be unable to sustain additional births, she talked about her sadness and concerns with a social worker until she felt "restored".

When her son entered school, she undertook graduate studies. Always a motivated and efficient student, she completed her doctorate in music and began a career as a professor of music in her early thirties. She retired at the age of 65 , shortly after her husband, who is three years older than she, retired from his position as a professor of physics at a different university. 
My initial impression during our first formal meeting was that Louise was somewhat more stooped than she had been several months previously. She is still taller than average height, slender and well-groomed. Her demeanor, the cut of her clothes, and her bearing indicate that she is an "aristocratic", highly educated, and charming person, despite the appearance of listlessness. Her eyes filled and overflowed with tears whenever our eyes met, and at times she burst into tears.

She frequently expressed embarrassment at this "loss of control." She said that she was aware of some degree of emotional distress. She owed her courage in contacting me to the encouragement of her husband and physician, who seemed to have faith in her recovery. She was convinced, she said, that she was losing her memory, even though others around her saw no signs of this. Even though her friends and family were kind to her, the words of a poem by Rainer Marie Rilke kept running through her head:

\section{And there she stood, as strange as something loaned \\ Slowly growing old and blind, and was not prized.}

She had been reassured that people who are really losing their memory are generally unaware of that fact. The last part of the poem referred, she knew, to her own feelings about herself. I am feeling very "down on myself," she said. I feel that I can do nothing right--and things can only get worse until I am of no use to anyone at all, even myself. Despite these feelings, she again said that she wanted very much to get better, and feel good again. She no longer enjoyed her friends and former activities the way she once did, and especially since she feared the frequent, uncontrolled and unexpected crying. As she found herself less and less able to control her crying even when engaging in otherwise pleasurable activities like entertaining friends, she was increasingly blaming herself for her outbursts and making matters worse. She had been told that the Parkinson's disease, and the medications used to treat it, are both associated with depression. Nevertheless, unlike her attitude during our first meeting, she expressed the opinion that the feelings were now a problem in themselves. "Above all, I don't want to keep feeling like this," she said, "and right now I feel that I will never feel any better without help."

\section{History of the Problem}

In older adults, more frequently than in younger persons, depression is often associated with precipitating events--even when there is no prior history of a depressive disorder [8,9]. In the case of Louise $\mathrm{H}$., I was readily able to elicit recent events that may have triggered the present reaction.

Louise remembers feeling a bit uneasy when, on her 62nd birthday, she suddenly recalled that both of her parents--who had always been vigorous and appeared healthy--had died suddenly and unexpectedly during their sixties when she, herself, was in her 40s). Two years later, when Louise was 64 , her husband had a mild heart attack. He had always appeared to be a "perfect physical specimen," so that although he was not seriously incapacitated, many lifestyle and attitude changes resulted from what they both considered a serious warning. That year, at the age of 67, he retired, earlier than he had expected.

Following a semester leave, taken to insure her husband's recovery and comfort, Mary returned to her department. She was, at that point, feeling good about her own professional achievements. 
(She was chair of her department, and had previously had a successful experience as dean of a smaller college). Upon returning to work, though, she discovered that a prominent colleague (whom she had recently hired) had, as Acting Chair, worked hard to undermine her credibility both with the department and the administration. He had charged her with leaving him with an "administrative mess," being "way past her prime" as a musician, and therefore unable to serve as mentor/role model to her doctoral students. Shortly after she returned to work, she learned that two of her female friends, both married professional women with whom she and her husband regularly played Bridge, had recently died. These deaths occurred suddenly and unexpectedly, during their sixties.

She, herself, was feeling well enough. However, believing that she deserved to retire while she and her husband were still well enough to realize their lifelong goal of exotic travel, she began to think that she should retire earlier than originally contemplated (i.e., at age 70). During this time period, Louise who had apparently been an optimistic and flexible person, continued to cope quite well. Troubled by the events at work, she worked at deriving more satisfaction from other activities. She and her husband are characteristically pleasant and extroverted people, who continued to socialize with friends. She participated in a wide range of activities, primarily at her church (with her husband and son), and her large circle of friends at church, and at in various sports (walking (with her husband), golf (with her husband), and tennis (with friends).

It was not until she retired, at the age of 67 (1 1/2 months after I first saw her), that she began to "have the blues." Thus, by the time that her doctor referred for psychotherapy, she was fully retired, and was "aware" that somehow she was "deteriorating".

At first, the diagnosis of Parkinson's disease was a relief. She had a condition with a name, and for which there are medications. She wasn't just suffering from "old age." Now, however, the full impact of her husband's and her own physical problems had "hit her," and the amount of money that they had to live on was far less than had been expected when they planned to retire at age 70 . Furthermore, the circumstances that led to her retirement troubled her, as she felt that it was not fully voluntary. A further loss was the loss of physical proximity to her one child, now 35 years old and still unmarried. Three months ago he had moved out of an apartment $11 / 2$ miles from the family's New Jersey home, to a house 46 miles away that he had purchased. One month before the H.s left Florida, a neighbor, their closest friend there, died of a heart attack at the age of 63 .

\section{Assessment}

The assessment in this case is based on information provided by Louise H's physician, by Louise H., and by her husband.

Louise was the only child of a hard-working couple, who emigrated from Sweden to Minnesota shortly before she was born. She recalled being brought up in the context of a large family, all of whom were sober, hard-working Swedes. Nevertheless, she recalls that many had a "twinkle" in their eye, and a bit of candy to give her when her mother wasn't looking. She recalls being a very active girl, who excelled in school--academically, musically, and athletically. She worked hard to please her parents, and felt that she succeeded quite well at the task. She remembers having a small group of friends, a high school "sweetheart", and two "broken hearts" in college--with plenty of support from her roommate to get through the "hard time." On balance, she remembers her childhood and early adolescence with fondness. 
Upon returning home after college, she felt somewhat restricted. Hence, she went to Europe to perform as a singer. There she met her husband, who was in the armed services, and never returned to live at home. Her parents approved of her husband, a New Jersey-born man of Scandinavian origin. He was well educated, tall enough to dwarf their tall daughter, and as bright, well-bred and witty as she. She recalls them all having good times when they were together, despite disagreements "typical," she believes, of the relationships between young adults and their parents.

She and her husband had long careers, and were supportive of one another--despite some sexism on his part. "Dinner always had to be put on the table, by me, no later than $7 \mathrm{pm}$, or he would sulk; he's a lot better now" she stated. None in the family, including their son, had serious problems that she could think of. She feels that their home has typically had an atmosphere of love and respect. Aside from the childhood illnesses that were "usual" when she was growing up (like strep throat, earaches, mumps, measles and flus), and the problems during the birth of her son, she recalls no significant physical illnesses.

No problems were apparent other than the problems with gait, mild decrements in memory, and her difficulty accepting her recent career limitations, especially as a musician. Also highly significant has been the PBA, which in her case results in outbursts of crying, in the absence of depressed affect.

The diagnoses are:

Parkinson's Disease, mild, 331.83 ICD 10-CM code.

Pseudobulbar Affect, code F48.2 (in section F40). This is a billable ICD-10-CM disorder that is referenced in the DSM 5.

\section{Intervention}

I chose psychodynamic psychotherapy for work with Louise $\mathrm{H}$.

Like other clinicians [10], I have found that the therapy modalities that are effective with younger persons--cognitive, behavioral, and psychodynamic--all constitute reasonable choices, depending on the circumstances. I have engaged in cognitive therapy, for example, with older adults unable or unwilling to acknowledge emotional distress, and without much capacity to relate to others. Louise $H_{\text {., }}$ on the other hand, is a person who has consistently expressed a desire to explore the meaning of her present suffering, and to face the "challenge of late life declines" in strength [11].

In the face of her current disenchantment, she felt hopeless. Nevertheless, she expressed willingness to work on structuring her vision, and her life. In our first and second formal meetings, for example, it became apparent that her retirement occurred under unexpected and disadvantageous circumstances, leading to extreme unhappiness about this facet of her life. As Atchley (1976) has pointed out, not all people suffer from "let downs" after retirement [12]. Many are well able to achieve reorientation and achieve a stable new lifestyle, without formal therapeutic help. When, as in the case of Louise $\mathrm{H}_{\text {., }}$ the retired individual has not achieved what she or he expected by retirement age, has less income than expected at retirement, experiences concomitant health decrements and diverse losses, then adjustment may be impaired. Such impairments may occur even among people with prior histories of good adjustment. The added fact of her PBA caused her embarrassment that, in turn led to social isolation-an issue that she 
wished to address in psychotherapy.

Louise has, indeed, identified certain concerns, or themes that she wants to address. First, there is the need to understand the contours of her own life, to put the present challenge into perspective. Second is the need to deal with her sense of failure in her career, combined with the sense of uselessness in a family in which she has no grandchildren. Other concerns include the diminution in physical health and strength, and losses of friends and family. This individual's personality traits are expected to be useful in aiding her recovery in therapy. These include her candor, interpersonal trust, the ability to relate well to others, a basic motivation to "get better," and her drive toward continued autonomy. Other assets include her capacity for insight, and her psychology-mindedness.

The overall aim of this theme-oriented, psychodynamic therapy $[13,14]$ is to understand the disturbing concerns and their roots, in order to deactivate their ability to undermine the patient's adjustment [15]. More specifically, goals include an exploration of her life span as it unfolded. This process is expected to include what Butler and Lewis [16] have termed "renunciation and restitution," followed by growth and renewal and perspective-taking. This formulation by Butler and Lewis is based, at least in part, on Erikson's theory [17]. For Louise, renunciation and restitution involves allowing herself to grieve, first of all, that which she has lost, while finding the courage to see things as they are. Second, is the striving toward self-understanding, while taking realistic problems and declines into account. All of this requires--and is expected to enhance-perspective, the ability to see herself and her life as a whole. An additional goal is to find and engage in personally meaningful activities.

Two specific interventions are and, I expect, will continue to be employed. First is life review. At this point in therapy, Louise is filling most of the 50-minute hours with a history of her life--an activity which is reportedly giving her a sense of relief. She has independently begun a journal at home, which she is sharing with her husband. This process has consumed many sessions, as she re-experiences many emotions and reactions--joy, sadness, and sometimes remorse and repentance. The latter has been over her "guilt" at not living closer to her parents before their own early and unanticipated deaths.

The second intervention is based on my own work, in which the helping of others has been found to serve as a way to cope with stress, particularly during later life $[2,17]$. For many older people who feel "useless," the therapist can successfully encourage involvement in helping activities. For Louise one possible activity may be a volunteer position as church organist. This opportunity has already been offered to her by her minister who cannot afford to pay an organist at present, and greatly admires her talent. Louise feels unable as yet to undertake any but minimal involvement but is intrigued, and has begun to seriously practice. Still another possibility, if she continues to feel unable to teach voice because her own voice has become "erratic and uncertain" due to the Parkinson's disease, may be to use her rich background in musical pedagogy to work with teachers. Much in the same way that retired executives help young entrepreneurs through government-sponsored activities such as SCORE (Senior Core of Retired Executives), Louise. may eventually consider serving as a mentor to offer her help in public school music programs, in which incompletely trained music teachers are often overwhelmed by the lack of time and resources [18]. 


\section{Conclusion}

At this time, shortly after the onset of therapy, Louise. is already responding positively. I am primarily listening to an outpouring of feelings, thoughts and memories, a process which is reportedly beginning to enhance her coping. Positive transference (and, obviously, positive countertransference) are already quite apparent.

Hence, at the present time, to quote Doris Lessing in the Diaries of Jane Somers, I wait for when... (she) trust(s) me enough to tell me... tales so full of history. I ask, "Tell me, what did you wear on your wedding day?" And for some reason, there's always a laugh, a smile... and I sit and listen, listen.

\section{Author Contributions}

Elizabeth Midlarsky did all the work.

\section{Competing Interests}

The author has declared that no competing interests exist.

\section{References}

1. Blazer D. Depression. In: The encyclopedia of aging. 4th ed. New York: Springer; 2006. p. 303306.

2. Midlarsky E, Pirutinsky S, Chakrabarti D, Cohen F. Visualized prosocial behavior and emotion in late life. J Posit Psychol. 2018; 13: 485-493.

3. Morin RT, Midlarsky E. Depressive symptoms and cognitive functioning among older adults with cancer. Aging Ment Health. 2018; 22: 1465-1470.

4. Beutler LE, Scogin F, Kirkish P, Schretlen D, Corbishley A, Hamblin D, et al. Group cognitive therapy and alprazolam in the treatment of depression in older adults. J Consult Clin Psychol. 1987; 55: 550-556.

5. Baldwin R. Depressive illness. In: Psychiatry in the elderly. Oxford: Oxford University Press; 1991. p. 676-719.

6. Gotham A, Brown R, Marsden C. Depression in Parkinson's disease: A quantitative and qualitative analysis. J Neurol Neurosurg. 1986; 49: 381-389.

7. Rudolph JL, Fonda JR, Hunt PR, McGlinchey RE, Milberg WP, Reynolds MW, et al. Association of pseudobulbar affect symptoms with quality of life and healthcare costs in veterans with traumatic brain injury. J Affect Disord. 2016; 190: 150-155.

8. La Rue A, Dessonville C, Jarvik LF. Aging and mental disorders. In: Handbook of the psychology of aging. New York: Van Nostrand Reinhold; 1985.

9. Pfeiffer E. Psychotherapy with elderly patients. In: Geriatric psychiatry. New York: Grune \& Stratton; 1976. p. 191-205.

10. Thompson LW, Gallagher D, Breckenridge JS. Comparative effectiveness of psychotherapies for depressed elders. J Consult Clin Psychol. 1987; 55: 385-390.

11. Frankl V. Psychotherapy and existentialism. New York: Simon and Schuster; 1968.

12. Atchley RC. The sociology of retirement. Cambridge, Mass: Schenkman; 1976.

13. Rosenfeld AH. New views on older lives. Rockville, MD: US Public Health Service; 1978. 
14. Marshall W, Barbaree H. Personality, impulse control, and adjustment disorders. In: Adult psychopathology and diagnosis. New York: Wiley; 1991. p. 360-391.

15. Knight R. Psychotherapy with older adults. Thousand Oaks, CA: Sage; 2004.

16. Butler RN, Lewis ME. Aging and mental health. Columbus, OH: CE Merrill; 1982.

17. Midlarsky E, Kahana E. Altruism in later life. Newbury Park, CA: Sage; 1994.

18. Solis J, Brink TL. Adlerian approaches in geriatric psychotherapy: Case of an American widow. J Individ Psychol. 1989; 45: 178-185.

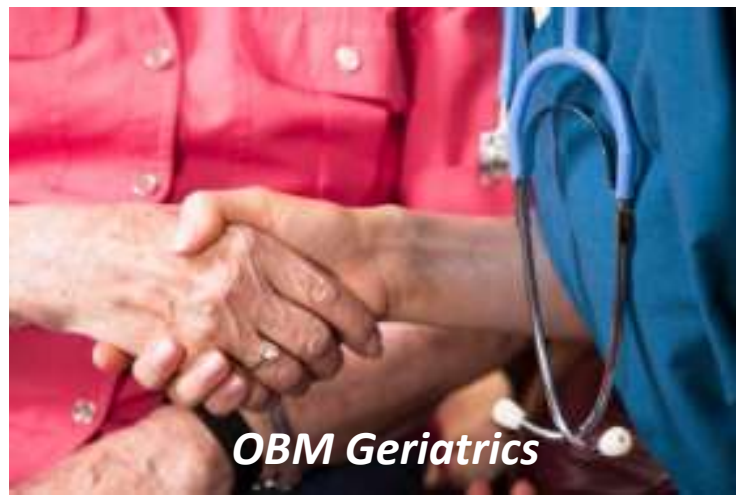

Enjoy OBM Geriatrics by:

1. Submitting a manuscript

2. Joining in volunteer reviewer bank

3. Joining Editorial Board

4. Guest editing a special issue

For more details, please visit:

http://www.lidsen.com/journals/geriatrics 